\title{
SOSIALISASI PENULISAN KARYA ILMIAH BAGI MAHASISWA DI STKIP PERSADA KHATULISTIWA SINTANG
}

\author{
Nelly Wedyawati ${ }^{1}$, Anyan ${ }^{2}$, Thomas Joni Verawanto Aristo ${ }^{3}$ \\ ${ }^{123}$ STKIP Persada Khatulistiwa Sintang \\ Email: nellywedyawati@ymail.com, anyanright@gmail.com.thomaspaoh@gmail.com
}

\begin{abstract}
One focus of the activity of the LPPM STKIP Persada Khatulistiwa Sintang as an institution was to hold a socialization of "thesis writing guidelines". The activity was intended as an activity in the field of research; as information to students about the systematics and style of the thesis environment. Add insight into educational research methodologies so that participants have ideas and creativity in the field of research, motivating students in the thesis preparation process. The procedure of service activities goes through several stages namely identifying learning needs with the results in the form of material in the form of knowledge, including: (1) understanding the characteristics of workshop participants, (2) mastery of writing concepts and systematic works of scientific work (3) understanding of workshop planning (4) workshop implementation along with methods and techniques and (5) evaluation in the workshop. Evaluation of activities resulted in conclusions (1) Activities carried out as many as five stages were carried out well attended by the leadership, four presenters and 227 students who were preparing the thesis as participants of the activity. (2) The results of the direct evaluation show that students understand and receive information well about the systematic writing and style of the thesis environment at STKIP Persada Khatulistiwa. (3) Students have additional insights into educational research methodologies so that participants have ideas and creativity in preparing research and conducting research. (4) Students were motivated in the thesis preparation process. (5) Students understand how to prepare articles from the results of research as graduation requirements in the STKIP Persada Khatulistiwa Sintang environment.
\end{abstract}

Keywords: Socialization, Scientific Writing, Thesis, Students

\begin{abstract}
Abstrak: Salah satu fokus kegiatan lembaga LPPM STKIP Persada Khatulistiwa Sintang adalah mengadakan sosialisasi "pedoman penulisan skripsi". Kegiatan ditujukan sebagai kegiatan pada bidang penelitian; sebagai informasi kepada mahasiswa tentang sistematika dan gaya selingkung skripsi. Menambah wawasan mengenai metodologi penelitian pendidikan sehingga peserta memiliki ide dan kreativitas dalam bidang penelitian, memotivasi mahasiswa dalam proses penyusunan skripsi. Prosedur kegiatan pengabdian melalui beberapa tahapan yaitu mengidentifikasi kebutuhan belajar yang hasilnya berupa materi dalam bentuk pengetahuan, meliputi: (1) pemahaman karakteristik peserta workshop, (2) penguasaan konsep tata tulis dan sistematika karya ilmiah (3) pemahaman perencanaan workshop (4) pelaksanaan workshop beserta metode dan teknik dan (5) evaluasi dalam workshop. Evaluasi kegiatan menghasilkan kesimpulan (1) Kegiatan yang dilaksanakan sebanyak lima tahap terselenggara dengan baik dengan dihadiri oleh pimpinan, empat pemateri dan 227 mahasiswa yang sedang menyusun skripsi sebagai peserta kegiatan. (2) Hasil evaluasi langsung menunjukkan bahwa mahasiswa memahami dan menerima informasi dengan baik tentang sistematika penulisan dan gaya selingkung skripsi di STKIP Persada Khatulistiwa. (3) Mahasiswa memiliki tambahan wawasan mengenai metodologi
\end{abstract}


penelitian pendidikan sehingga peserta memiliki ide dan kreativitas dalam menysuun riset dan melaksanakan penelitian. (4) Mahasiswa termotivasi dalam proses penyusunan skripsi. (5) Mahasiswa memahami cara penyusunan artikel dari hasil penelitian sebagai persyaratan wisuda di lingkungan STKIP Persada Khatulistiwa Sintang.

Kata Kunci: Sosialisasi, Karya Tulis Ilmiah, Skripsi, Mahasiswa.

\section{PENDAHULUAN}

Kemahiran menulis adalah salah satu keahlian umat manusia yang paling penting. Bahkan tulisan diyakini sebagai salah satu unsur utama pembentuk peradaban manusia saat ini. Pewarisan ide dan pemikiran kompleks dari generasi ke generasi untuk kemudian dikembangkan hanya dapat dilakukan secara efektif melalui tulisan (Wardhani, 2017). Salah satu penentu kualitas bangsa adalah pendidikan. Semakin bagus pendidikan yang dimiliki oleh suatu bangsa, semakin berkualitas pula bangsa tersebut. Jadi, seseorang yang mengaku dirinya berbudaya seharusnya menjadikan aktivitas menulis sebagai salah satu kegiatan utamanya sehari-hari. Menulis adalah kebutuhan pokok, sebagaimana halnya pangan dan sandang.

Dalam kehidupan modern, pada hakikatnya tak seorang pun yang bisa mengelak dari tulisan. Seorang ibu rumah tangga yang mencatat pengeluaran sehari-hari, pedagang sayur yang membuat daftar sayur mayur yang perlu dipesan atau sudah terjual, maupun kaum remaja yang chatting di facebook pada hakikatnya menggunakan kemahiran menulis (Suci, 2018). Kebutuhan menulis dirasakan lebih nyata oleh kaum intelektual, baik mahasiswa maupun mereka yang menduduki jabatan fungsional, seperti guru, dosen, dan peneliti. Bagi mereka, menulis tidak hanya sekedar kebutuhan melainkan keharusan. Sebelum menyelesaikan studinya, setiap mahasiswa diwajibkan menulis ringkasan buku, makalah, maupun laporan penelitian.

Bagi guru, dosen, dan peneliti, menulis artikel untuk seminar atau untuk diterbitkan di media massa maupun jurnal penelitian merupakan syarat mutlak untuk mendapatkan angka kredit untuk menaikan jenjang jabatan fungsionalnya. Tulisan ini membahas penulisan karya ilmiah, yakni ragam bahasa tulisan yang menjadi konsumsi kaum intelektual, termasuk mahasiswa, guru, dosen, dan peneliti Kurniadi, 2017). Pembahasan difokuskan pada hakikat, struktur, 
dan proses penulisan karya ilmiah.

Pemahaman terhadap topik-topik tersebut diharapkan dapat lebih memampukan pembaca untuk menghasilkan karya ilmiah yang baik (Rifai, 1995).

Perguruan tinggi melalui program pengabdian kepada masyarakat. Kegiatan tersebut antara lain berupa pelatihan-pelatihan yang berkaitan dengan proses belajar mengajar (PBM) dan pengembangan profesi, antara lain pelatihan penelitian tindakan kelas, penulisan karya ilmiah, literasi, dan pembelajaran sastra. Pelatihan penulisan karya ilmiah penting diberikan kepada guru mengingat masih banyak guru yang kesulitan membuat karya ilmiah. Padahal, guru harus menjadi pendidik. Menulis karya ilmiah merupakan syarat mutlak bagi guru yang akan naik pangkat. Mengingat pentingnya hal tersebut maka mahasiswa yang sedang menempuh perkuliahan pada Sekolah Tinggi Keguruan dan Ilmu Pendidikan (STKIP) Persada Khatulistiwa wajib dibekali dengan keterampilan menulis karya tulis ilmiah sebagai softskills di masa mendatang.
Suatu perguruan tinggi mempunyai kewajiban menyelenggarakan kegiatan pengajaran, penelitian dan pengabdian kepada masyarakat, yang dikenal dengan nama Tri Dharma Perguruan Tinggi. Untuk mendukung dosen yang kompeten diketiga bidang tersebut, Lembaga Penelitian dan Pengabdian kepada Masyarakat (LPPM) STKIP Persada Khatulistiwa memfasilitasi beberapa kegiatankegiatan penelitian dan pengembangan serta pengabdian kepada masyarakat.

Salah satu fokus kegiatan dalam kegiatan penelitian LPPM mengadakan sosialisasi Pedoman Penulisan Skrispsi STKIP Persada Khatulistiwa Sintang dan Metodologi Penelitian Pendidikan". Sosialiasi Pedoman berhubungan dengan revisi terbaru Pedoman Penulisan Karya Ilmiah STKIP Persada Khatulistiwa, dengan sosialiasi ini diharapkan bahwa mahasiswa-mahasiwa dimudahkan dalam penyusunan laporan akhir yang disebut dengan Skripsi. Kegiatan Diklat ini ditujukan untuk mengadakan kegiatan dalam bidang penelitian, Menginformasikan kepada mahasiswa perubahan sistematika penulisan skripsi STKIP Persada Khatulistiwa, menambah 
wawasan peserta mengenai metodologi penelitian pendidikan sehingga peserta memiliki ide dan kreativitas dalam bidang penelitian, memotivasi peserta dalam proses penyusunan skripsi.

\section{METODE PELAKSANAAN}

Pelaksanaan kegiatan melalui perancangan beberapa tahapan yaitu sebagai berikut:

1. Tahap Perencanaan. Pada tahap perencanaan kegiatan yang akan dilakukan adalah mengidentifikasi kebutuhan belajar yang hasilnya berupa materi dalam bentuk pengetahuan, meliputi: (1) pemahaman karakteristik peserta workshop, (2) penguasaan konsep tata tulis dan sistematika karya ilmiah, (3) pemahaman perencanaan workshop, (4) pelaksanaan workshop beserta metode dan teknik, dan (5) evaluasi dalam workshop,.

2. Kebutuhan materi dalam bentuk keterampilan, meliputi: (1) penyusunan program workshop,dan jadwal workshop,

(2) penyusunan persiapan pelaksanaan workshop,(3) pelaksanaan workshop, dan

evaluasi workshop.

3. Tahap Pengorganisasian. Tahap pengorganisasian dalam pengabdian ini meliputi beberapa kegiatan seperti (1) mengenalkan tentang karya ilmiah kepada mahasiswa, (2) meningkatkan keefektifan penulisan karya ilmiah sebagai sarana pembelajaran pada mahasiswa, menyusun kerangka penulisan karya ilmiah, (4) melaksanakan workshop,(5) melaksanakan evaluasi pelatihan.

4. Tahap Pelaksanaan Workshop. Pengkondisian awal sebelum workshop inti dimulai meliputi kegiatan (1) menciptakan suasana yang kondusif untuk mengikuti workshop,

memberikan pemahaman terhadap langkah-langkah kegiatan yang harus ditempuh selama workshop, menyampaikan kebermanfaatan mengikuti kegiatan workshop, menginformasikan berbagai kegiatan dalam pelaksanaan workshop secara keseluruhan yang harus dilakukan peserta 
workshop meliputi kegiatan teori dan praktik.

5. Evaluasi. Evaluasi secara langsung dilakukan pada saat workshop yang mencakupi: (1) bagaimana keseriusan mahasiswa dalam mengikuti kegiatan workshop

bagaimana pengetahuan mahasiswa tentang hakikat penelitian, (3) bagaimana pengetahuan mahasiswa tentang hakikat artikel ilmiah dan kaidah selingkungnya, serta

kemampuan mahasiswa mempraktikkan menyusun artikel ilmiah.

\section{HASIL DAN PEMBAHASAN}

Kegiatan pengabdian ini dilaksanakan pada hari kamis, tanggal 30 Januari 2020 selama satu hari, mulai pukul 07.30 s.d. 12.00 bertempat di Auditorium STKIP Persada Khatulistiwa. Jumlah peserta kegiatan berjumlah 277 peserta yang terdiri dari semua program studi semester tujuh yang mengambil mata kuliah skripsi. Rincian kegiatan disajikan dalam tabel 1. Tahapan perencanaan dilakukan dengan briefing antara panitia dan pemateri. (Wedyawati, 2019) Kegiatan pembekalan dalam pengabdian kepada masyarakat ini adalah metode workshop dalam bentuk pelatihan dan pendampingan sampai menghasilkan produk. Produk yang diperoleh adalah buku pedoman dan modul-modul pemateri.

Pada sesi pertama adalah persiapan kegiatan dengan absensi kehadiran dan pembukaan oleh Pimpinan Perguruan Tinggi. Selanjutnya adalah acara inti pelaksanaan pengabdian diawali dengan penyampaian materi tentang (1) persyaratan penyusunan skripsi, (2) sistematika proposal skripsi dan skripsi, (3) bahasa dan teknik penulisan skripsi dan (4) menulis artikel ilmiah dari hasil penelitian. Materi pertama tentang "persyaratan penyusunan skripsi" disampaikan oleh Dr. Hilarius Jago Duda, S.Si., M.Pd. Dalam sesi ini dibahas mengenai persyaratan akademik bagi mahasiswa yang ingin menyelesaikan skripsi. Selanjutnya, materi kedua tentang "sistematika proposal skripsi dan skripsi” disampaikan oleh Nelly

Wedyawati, S.Si., M.Pd. dalam pembahasan ini dibahas mengenai jenis-jenis sistematika untuk berbagai macam pendekatan penelitian antara lain; penelitian kuantitatif, kualitatif, PTK dan penelitian pengembangan berdasarkan buku pedoman penulisan 
karya ilmiah di STKIP Persada

Khatulistiwa Sintang (LPPM, 2019).

Disampaikan juga tentang

karakteristik penelitian pada STKIP

Persada Khatulistiwa yaitu pada

Bidang pendidikan difokuskan pada eksplorasi permasalahan dan atau pemecahan masalah pendidikan dan pengajaran pada jenjang pendidikan Pendidikan Tinggi, serta pada jalur pendidikan luar sekolah termasuk pendidikan keluarga. Bidang non pendidikan difokuskan pada permasalahan pada bidang keilmuan yang sesuai dengan program studi mahasiswa. (Observasi lapangan dan/atau penelaahan pustaka.

Tabel 1. Rundown acara kegiatan workshop

\begin{tabular}{|c|c|c|}
\hline $\begin{array}{c}\text { Ruang } \\
\text { Waktu }\end{array}$ & $\begin{array}{c}\text { Pukul } \\
\text { (Wiba) }\end{array}$ & Kegiatan \\
\hline \multirow{7}{*}{$\begin{array}{l}\text { Kamis } \\
\mathbf{3 0} \\
\text { Januari } \\
\mathbf{2 0 2 0}\end{array}$} & $\begin{array}{c}07.30 .- \\
08.00\end{array}$ & Absensi (Panitia) \\
\hline & $\begin{array}{c}08.00- \\
08.30\end{array}$ & $\begin{array}{c}\text { Pembukaan } \\
\text { (Ketua Badan } \\
\text { Perkumpulan Karya } \\
\text { Bangsa Sintang) }\end{array}$ \\
\hline & $\begin{array}{c}08.30- \\
09.30\end{array}$ & $\begin{array}{c}\text { Persyaratan Penyusunan } \\
\text { Skripsi } \\
\text { (Ketua STKIP Persada } \\
\text { Khatulistiwa Sintang) }\end{array}$ \\
\hline & $\begin{array}{c}09.30- \\
10.30\end{array}$ & $\begin{array}{c}\text { Sistematika Proposal } \\
\text { Skripsi dan Skripsi } \\
\text { (Nelly Wedyawati, S.Si., } \\
\text { M.Pd.) }\end{array}$ \\
\hline & $\begin{array}{c}10.30- \\
11.15\end{array}$ & $\begin{array}{c}\text { Bahasa dan Teknik } \\
\text { Penulisan Skripsi } \\
\text { (Thomas Joni Verawanto } \\
\text { Aristo, M.Pd.) }\end{array}$ \\
\hline & $\begin{array}{c}11.15- \\
12.00\end{array}$ & $\begin{array}{c}\text { Menulis } \\
\text { Artikel dari } \\
\text { Hasil } \\
\text { Penelitian } \\
\text { (Anyan, S.Kom, M.Kom.) }\end{array}$ \\
\hline & $\begin{array}{l}12.00- \\
\text { selesai }\end{array}$ & $\begin{array}{c}\text { Penutup: Pembagian } \\
\text { Sertifikat \& Makan Siang } \\
\text { (Panitia) }\end{array}$ \\
\hline
\end{tabular}

Dalam sesi ketiga dibahas mengenai "bahasa dan teknik penulisan skripsi”. Materi ketiga disampaikan oleh Thomas Joni

Verawanto Aristo, M.Pd., misalnya penggunaan ejaan sesuai dengan Ejaan Bahasa Indonesia (EBI), penulisan rujukan dalam teks, dan penulisan daftar pustaka. Pada materi ini, disampaikan bahwa penulis skripsi harus teliti dan cermat dalam membuat desain skripsi, halhal yang berkaitan dengan teknis penulisan, sanduran, dan ejaan adalah sesuatu yang seharusny tidak menjadi topik utama dalam bimbingan skripsi. Teknik penulisan dan format penulisan merupakan hal dasar yang harus dikuasai oleh mahasiswa sebagai penulis skripsi. Metode sosialisasi ini berupa penyuluhan, pelatihan dan pengenalan yang dapat menstimuliasi minat (Aristo, 2019), sehingga mereka merasa termotivasi untuk mengerjakan skripsi dengan baik, serta dapat menghindari kesalahan-kesalahan umum dalam menulis. Adapun materi terakhir adalah tentang "menulis artikel dari hasil penelitian" disampaikan oleh Anyan, S.Kom., M.Kom. Pada sesi ini dijelaskan tentang karya ilmiah, khususnya yang berupa artikel hasil penelitian mahasiswa 
yang dapat ditulis oleh mahasiswa dan dosen pembimbing terkait dengan pengembangan diri dan keprofesian serta cara menyusun karya ilmiah yang diangkat dari hasil penelitian. Mulai dari Judul Artikel, Abstrak, Pendahuluan, Metode Penelitian, Hasil dan Pembahasan, Kesimpulan, dan terkahir Daftar Pustaka. Hasil evaluasi selama kegiatan menunjukkan bahwa selama ini mahasiswa belum memahami dengan baik cara menyusun artikel ilmiah hasil penelitian. Peserta beranggapan satu laporan hasil penelitian hanya dapat dibuat satu artikel. Padahal, tidak demikian. Satu laporan skripsi dapat dibuat menjadi beberapa artikel ilmiah tergantung rumusan masalah yang ada dalam penelitian tersebut. Misalnya dalam penelitian tersebut terdapat tiga rumusan masalah, maka hasil penelitian tersebut dapat dibuat menjadi tiga artikel. Berikut adalah gambar dari kegiatankegiatan. Berikut adalah gambar dari kegiatan-kegiatan.

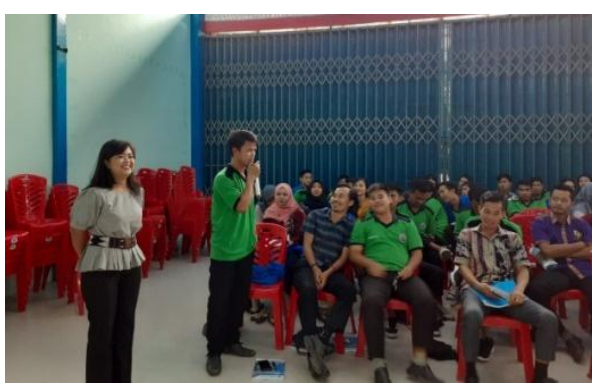

Gambar 1. Sesi diskusi dan tanya jawab peserta

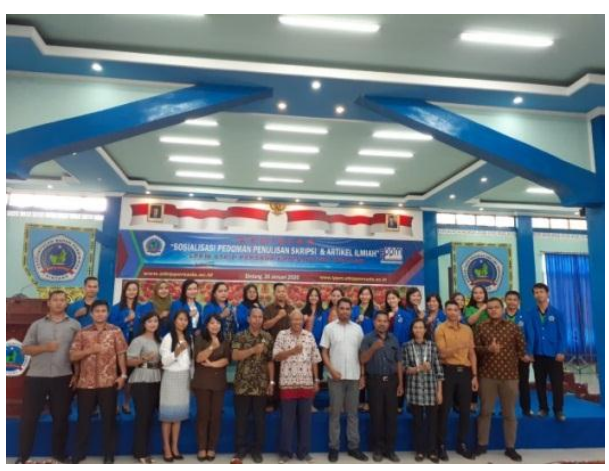

Gambar 2. Dokumentasi akhir kegiatan

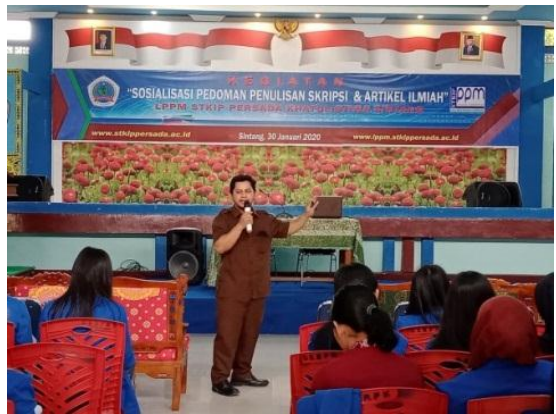

Gambar 3. Pemateri tentang Bahasa dan Teknik Penulisan Skripsi

Kegiatan diakhiri dengan sesi tanya jawab dan konsultasi. Dalam sesi ini para peserta dapat mengonsultasikan rencana penelitian yang sudah dimiliki untuk dibahas. Dalam kegiatan konsultasi dan bimbingan draft proposal penelitian yang mereka bawa, banyak ditemukan tentang kesalahan 
ejaan, cara pengutipan yang belum sesuai kaidah, dan banyak kalimat yang tidak efektif. Pada umumnya mereka belum menguasai tentang tata tulis dan penyusunan kalimat efektif.

Secara umum kegiatan pengabdian ini berjalan lancar dan mahasiswa mengikuti kegiatan ini dengan penuh antusias karena mereka merasakan secara langsung manfaat dari kegiatan tersebut. Mereka mengaku banyak hal baru yang diperoleh. Terutama, mereka mendapat pengetahuan yang dapat diaplikasikan untuk mendukung penyelesaian kuliah, pencapaian gelar atau pengembangan karir. Bahkan, ada beberapa di antaranya yang melanjutkan konsultasi sampai tuntas membahas proposal penelitian. Akhir kegiatan sebagai usaha follow up sesuai dengan pernyataan bahwa (Siregar, 2019) Perubahan perilaku perlu di monitoring terus menerus, maka kegiatan penulisan proposal dan artikel akan diserahkan kepada masing-masing dosen pembimbing skripsi mahasiswa.
Berdasarkan Evaluasi kegiatan yang telah dilakukan, maka dapat dilaporkan bahwa kegiatan:

1. Kegiatan yang dilaksanakan sebanyak lima tahap terselenggara dengan baik dengan dihadiri oleh pimpinan, empat pemateri dan 227 mahasiswa yang sedang menyusun skripsi sebagai peserta kegiatan.

2. Hasil evaluasi langsung menunjukkan bahwa mahasiswa memahami dan menerima informasi dengan baik tentang sistematika penulisan dan gaya selingkung skripsi di STKIP Persada Khatulistiwa.

3. Mahasiswa memiliki tambahan wawasan mengenai metodologi penelitian pendidikan sehingga peserta memiliki ide dan kreativitas dalam menysuun riset dan melaksanakan penelitian.

4. Mahasiswa termotivasi dalam proses penyusunan skripsi.

5. Mahasiswa memahami cara penyusunan artikel dari hasil penelitian sebagai persyaratan wisuda di lingkungan STKIP Persada Khatulistiwa Sintang. 
Aristo, Thomas. J. V. 2019. Stimulating Students' Interest in Listening Through Music. Jurnal. Jurnal Pengabdian Masyarakat Khatulistiwa. Volume 2 Nomor 1 halaman 1016.

DOI: https://doi.org/10.31932/jp mk.v2i1.424. E-ISSN 26205300.

Kurniadi, Fajar. 2017. Penulisan Karya Tulis Ilmiah Mahasiswa dengan Media Aplikasi Pengolah Kata. Jurnal. AKSIS: Jurnal Pendidikan Bahasa dan Sastra Indonesia Volume 1 Nomor 2, e-ISSN: 2580-9040 http://doi.org/10.21009/AKSIS.

Lembaga Penelitian dan Pengabdian Masyarakat. 2019. Buku Pedoman Penulisan Skripsi STKIP Persada Khatulistiwa. Sintang: dokumen LPPM.

Marselina, Suci. 2018. Peningkatan keterampilan menulis karya ilmiah melalui strategi belajar kooperatif tipe Group Investigation siswa kelas XI MAN I kota Sungai Penuh. Jurnal. PENTAS: Jurnal Ilmiah Pendidikan dan Sastra Indonesia. Volume 4 Nomor 1 Halaman 14-21. ISSN (Print)
2442-787X. ISSN (Online) 2579-8979 14-21

Rifai, Mien A. 1995. Pegangan Gaya Penulisan, Penyuntingan dan Penerbitan Kary Ilmiah Indonesia. Yogyakarta: Gajah Mada University Press.

Siregar, M., Wedyawati, N. 2019. Program Safe Drinking Water Treatment Wahana Visi Indonesia Kabupaten Sintang. Jurnal. Jurnal Pengabdian Masyarakat Khatulistiwa. Volume 2 Nomor 2 halaman 110-115.

DOI: https://doi.org/10.31932/jp mk.v2i2.557. E-ISSN 26205300 .

Wardhani. 2007. Menulis Karya Ilmiah. Bandung: Nusa Media.

Wedyawati, N., Lisa, Y. 2019. Peningkatan Rasa Kesadaran Bahaya Minuman Keras dengan Pendekatan Eksperimen Melalui PPL-KKM di SDN 11 Bora Desa Kecamatan Sayan Kabupaten Melawi. Jurnal. Jurnal Pengabdian Masyarakat Khatulistiwa. Volume 2 Nomor 1 halaman 17-25. DOI: https://doi.org/10.31932/jp mk.v2i1.425 